Aldona Molesztak*

Bydgoszcz

\title{
Rodzina w sytuacji zatrudnienia rodzica poza miejscem zamieszkania
}

Rozwój nauki w sferze cyfrowej, komunikacyjnej i technicznej wpłynął znacząco na funkcjonowanie rodziny. W związku z tym rodzinę traktować należy wielopłaszczyznowo i wielowątkowo. Wzrost liczby rozwodów i rodzin monoparentnych, pojawienie się alternatywnych form życia rodzinnego, zatrudnianie rodziców poza miejscem zamieszkania, zwiększenie czasu pracy, nastawienie ludzi na realizację siebie oraz rozpowszechniony konsumpcjonizm ujawniły wiele nowych zagadnień. Również urbanizacja, industrializacja, nowa hierarchia dóbr, pluralizm wartości znacząco oddziaływają na życie rodzinne'. Sposób reagowania na wyżej wymienione

* Dr Aldona Molesztak jest adiunktem w Zakładzie Myśli Społecznej i Edukacji Środowiskowej w Instytucie Pedagogiki Uniwersytetu Kazimierza Wielkiego w Bydgoszczy. Adres: Instytut Pedagogiki UKW, Zakład Myśli Społecznej i Edukacji Środowiskowej, ul. Powstańców Wlkp. 2, 85-090 Bydgoszcz; adres e-mail: amoleszt@ukw.edu.pl.

${ }^{1}$ Por. m.in.: Krystyna Slany, „Małżeństwo i rodzina w zglobalizowanym świecie”, Problemy Rodziny 4/5/6 (2001): 3-10; Krystyna Slany, „Ponowoczesne rodziny - konstruowanie więzi i pokrewieństwa”, w: Zagadnienia matżeństwa i rodzin w perspektywie feministycznogenderowej, red. Krystyna Slany (Kraków: Wydawnictwo Uniwersytetu Jagiellońskiego, 2013), 45-64; Zbigniew Tyszka, Rodzina we wspótczesnym świecie (Poznań: Wydawnictwo Naukowe UAM, 2002); Jan Rostowski, Teresa Rostowska, „Małżeństwo - wczoraj, dzisiaj i jutro - w perspektywie psychologicznej”, w: Czlowiek u progu trzeciego tysiaclecia. Zagrożenia $i$ wyzwania, red. Mieczysław Plopa (Elblag: Wydawnictwo Elbląskiej Uczelni Humanistyczno-Ekonomicznej, 2005), 229-242; Barbara Harwas-Napierała, „Rodzina jako wartość a współczesność", w: Rodzina jako wartość w rozwoju człowieka, red. Barbara Har- 
zjawiska zależy w istocie tylko od człowieka. Rodzina to „barometr” stanu organizacji i dezorganizacji społeczeństwa. „Wszystkie korzystne i niekorzystne zjawiska społeczne mają wpływ na jej kondycję"2. Człowiek dokonuje wyborów względem rodziny i społeczeństwa, w którym żyje, a za podejmowane decyzje ponosi odpowiedzialność. W efekcie najistotniejsze dla dorosłego człowieka i dziecka są transformacje występujące w rodzinie. Od rodziny, jej wspólnotowości zależy przyszłość jej członków. Jak stwierdza Anna Kwak: „Schyłek rodziny czy wręcz jej zamieranie jest wynikiem osłabienia instytucjonalnych cech rodziny, w tym przejęcia jej funkcji przez inne instytucje, oraz efektem nietrwałości związków, utraty wartości kulturowej rodziny na rzecz indywidualizmu i egalitaryzmu, straty władzy na rzecz państwa, które stworzyło prawa broniące dobra rodziny i chroniące równości jej członków"3. Autorka, powołując się na Manuela Castellsa4, wymienia liczne zmiany zachodzące w społeczeństwie. Zalicza do nich między innymi przejawy niezależności zachowań reprodukcyjnych kobiet poprzez ograniczanie dzietności wraz z późnym urodzeniem pierwszego dziecka. Zaobserwowany został wzrost liczby rodzin z jednym rodzicem oraz gospodarstw jednoosobowych. Zmiany w rodzinie obejmują także najważniejsze wartości, pomagające $\mathrm{w}$ przezwyciężaniu pojawiających się trudności. I tak tradycyjnie „spoiwem” rodziny było dziecko, współcześnie natomiast wagę nadaje się relacjom pomiędzy małżonkami. To te relacje, a nie dzieci, są podstawą trwałości związku. Rośnie akceptacja dla kohabitacji, a związki gejowskie i lesbijskie stają się bardziej widoczne, chociaż nie są powszechnie akceptowane ${ }^{5}$.

was-Napierała (Poznań: Wydawnictwo Naukowe UAM, 2009), 11-24; Stanisław Kawula, „Rodzinne konteksty polskiej polityki społecznej”, w: Praca socjalna i polityka społeczna. Obszary współdziałania wobec wykluczenia społecznego, red. Krystyna Marzec-Holka, Anna Rutkowska, Magdalena Joachimowska (Bydgoszcz: Wydawnictwo Uniwersytetu Kazimierza Wielkiego, 2008), 43-58; Monika Żak, Życie rodzinne w sferze zawodów wysokiego ryzyka (na przykładzie zawodu policjanta) (Katowice: Wydawnictwo Uniwersytetu Śląskiego, 2015).

2 Bogusława Cholewa-Gałuszka, „Zagrożenia realizacji funkcji rodziny”, w: Rodzina $w$ świetle zagrożeń realizacji dotychczasowych funkcji. Szkice monograficzne, red. Wiesława Korzeniowska, Andrzej Murzyn, Urszula Szuścik (Katowice: Wydawnictwo Uniwersytetu Śląskiego, 2007), 29.

3 Anna Kwak, „Od i do małżeństwa i rodziny: «czas» rodziny - «czas» jednostki”, w: Wielość spojrzeń na matżeństwo i rodzinę, red. Anna Kwak, Mariola Bieńko (Warszawa: Wydawnictwo Uniwersytetu Warszawskiego, 2012), 49.

${ }^{4}$ Por. Manuel Castells, Siła tożsamości (Warszawa: Wydawnictwo Naukowe PWN, 2009), 258.

5 Kwak, „Od i do małżeństwa”, 50-51. 
Rodzina jest środowiskiem rozwoju wszystkich członków, a zatem osób dorosłych i dzieci. W jej klimacie pomiędzy członkami tworzącymi rodzinę występują wzajemnie zależne relacje, które mają swoje odniesienie w indywidualnym rozwoju ${ }^{6}$. Zmiany zachodzące na zewnątrz rodziny dotykają rodzinę, która w specyficzny sposób musi na nie reagować. Członkowie rodziny podlegają więc wpływom zewnętrznym: mikro-, mezo-, makrostruktur oraz społeczeństwa globalnego ${ }^{7}$. Następuje przemiana ról małżeńsko-rodzicielskich pod wpływem czynników etniczno-narodowych czy też ruchów feministycznych ${ }^{8}$.

Wśród wielu zagadnień dotyczących rodziny liczne dyskusje poświęcone są rodzinom czasowo niepełnym, nazywanym niekompletnymi, czyli takim, w których występuje czasowa nieobecność rodzica. Jest to problem od zawsze obecny w pedagogice. Możliwości wyjazdów za granicę w celach zarobkowych były przez wiele lat bardzo ograniczone. Do nielicznych wyjątków należeli żołnierze Polskich Sił Zbrojnych wyjeżdżający na misje wojskowe. Inne grupy ludności miały niewielkie możliwości podjęcia pracy za granica, chociaż i one występowały. Współcześnie Polacy mogą wyjeżdżać za granicę niemal bez ograniczeń, jednak z uwagi na przystapienie Polski do Unii Europejskiej 1 maja 2004 roku oraz wymaganą w coraz liczniejszych zawodach dyspozycyjność, nastapił znaczny wzrost liczby rodzin niepełnych czasowo. Zmiany społeczno-polityczne i cywilizacyjne umożliwiły nieograniczone przemieszczanie się ludzi. Najczęściej celem migracji są kraje Europy, a w dalszej kolejności USA i Kanada. Okres migracji jednego z rodziców nie jest więc precyzyjnie określony. Są to wyjazdy trwające od kilku miesięcy do roku. Zdarza się, że rodzic wyjeżdża nawet na kilka lat. Przeważnie skutki tego typu sytuacji są oceniane negatywnie. Rzadko wskazywane są pozytywne następstwa czasowej rozłąki. Niemniej jest to zagadnienie bardzo złożone i trudne w ocenie. Nie można uznać, że jest to jedyny problem dotykający rodzinę, jednak ze względu na wzrost liczby rodzin niepełnych czasowo i ujawnienie zjawiska „eurosieroctwa” stał się tematem popularnym i medialnym. Zjawisko to nie jest dobrze rozpoznane ze względu na trudności w uzyskaniu pełnych danych co do liczby osób zatrudnionych poza miejscem zamieszkania i czasu wyjazdu. W opinii Bartłomieja Walczaka statystyki Ministerstwa Edukacji Narodowej są nierzetelne. Wskazuje się

${ }^{6}$ Harwas-Napierała, ,Rodzina jako wartość”, 12.

7 Por. Zbigniew Tyszka, „Istotne zmiany w socjalizacji rodzinnej”, Problemy Rodziny 2-3 (2000): 31-34.

8 Por. Kawula, „Rodzinne konteksty”, 43-44. 
także na brak wiedzy nauczycieli na temat zatrudnienia rodziców uczniów poza miejscem stałego zamieszkania 9 .

Wprowadzenie w problematykę rodziny jest podstawą do określenia tematu niniejszego artykułu dotyczącego rodziny w sytuacji rodzica zatrudnionego poza miejscem zamieszkania. Jest to istotny problem współczesnej rodziny, chociaż - jak wskazano już wcześniej - jeden z wielu. Celem artykułu jest określenie rodziny w sytuacji zatrudnienia rodzica poza miejscem zamieszkania. $\mathrm{Z}$ tak sformułowanego celu wynika problem badawczy: jaka jest specyfika rodziny $w$ sytuacji zatrudnienia rodzica poza miejscem zamieszkania? Odpowiedź na tak postawiony problem uzyskana zostanie poprzez analizę zmian zachodzących we współczesnej rodzinie, zdefiniowanie rodzin niepełnych czasowo, przedstawienie rodzajów rodzin niepełnych czasowo oraz przyczyn i skutków rozłąki. Artykuł kończy ukazanie swoistości rodzin czasowo niepełnych na przykładzie żołnierzy wyjeżdżających na misje stabilizacyjne. Podejmowanie przez rodziców pracy poza miejscem zamieszkania w sytuacji bezrobocia czy z zamiarem podniesienia standardu życia, a także w celu ucieczki przed uzależnieniem i patologią jest coraz częściej spotykane. Przybywa także zawodów wymagających dużej mobilności i dyspozycyjności.

\section{Zmiany zachodzące we współczesnej rodzinie}

Współczesna rodzina przeżywa kryzys. Oceniając rodzinę z płaszczyzny tradycyjnej, z pewnością należy się z tym stanowiskiem utożsamiać. Jednak z uwagi na zmiany zachodzące w społeczeństwie, których nie sposób zatrzymać, można by zaryzykować twierdzenie, że rodzina znajduje się $\mathrm{w}$ transformacji. Zmiany te obejmują sferę socjalizacji i wychowania. Następuje zmniejszenie oddziaływania rodziców na rzecz silnych wpływów medialnych, szczególnie ofensywy megareklamowej, rozpowszechnia się konsumpcjonizm, narastają konflikty małżeńskie, brakuje wzajemnego porozumienia, wzrasta tempo życia i jego stresogenność. Ujawnia się dewaluowanie wartości moralnych, zanik kultu wytrwałości i solidności pracy. Nastąpiła zmiana organizacji życia, urzeczowienie relacji rodzinnych, autonomizacja.

${ }^{9}$ Bartłomiej Walczak, „Wychowawcze i edukacyjne konsekwencje «euromigracji» rodziców i opiekunów", Problemy Opiekuńczo-Wychowawcze 5 (2008): 25. 
Obserwuje się przejawy wzajemnej rywalizacji w życiu społecznym ${ }^{10}$. Anna Chmielewska, powołując się na Stanisława Kawulę, pisze o rodzinie ryzyka. Ryzyko jest efektem zjawiska bezrobocia i biedy, bezdomności, rozwodów oraz migracji rodziców. W czasie wolnym rodziny coraz częściej korzystają raczej z oferty kultury masowej lub popularnej niż z kultury wysokiej. Centra handlowo-rozrywkowe zaspokajają zarówno potrzebę konsumpcjonizmu, jak i rozrywki. Pod pozorem wspólnego spędzania czasu wolnego następuje zanik relacji między członkami rodziny, sprowadzonych do przekazywania informacji pozwalających na uczestniczenie w „handlowym festiwalu rozrywki". Relacje w czasie wspólnych działań rodziców i dzieci występują rzadziej ze względu na zmniejszenie się liczby wspólnych codziennych spotkań, urządzenia cyfrowe, pracę zawodową i ofertę czasu wolnego. Zgodnie $\mathrm{z}$ teorią społecznego uczenia się Bandury dzieci powielają model rodziny pochodzenia, a więc dziedziczą w ten sposób kulturę niedostatku materialnego czy emocjonalnego ${ }^{11}$.

Jednocześnie lansowany jest nowy model życia. W literaturze zwraca się uwagę na konsekwencje modelu osiagania szybkiej autonomii przez dzieci, powiązanej z nabyciem umiejętności samodzielnego funkcjonowania $\mathrm{w}$ życiu. Chodzi o radzenie sobie samemu w życiu, poleganie tylko na sobie. Na rodzinę ma także wpływ lansowanie wzorów zachodniego stylu życia rodzinnego. W tym klimacie akceptowanie wartości indywidualistycznych nie sprzyja rozwojowi współczesnej rodziny. Szczególnie młodzi ludzie, nastawieni na własny rozwój, autonomię, wolność, wysokie zadowolenie, przyjemności, nie przyczyniają się do wypracowania wspólnotowości w rodzinie. Takie podejście do wychowania sprzyja pojawianiu się nowych zjawisk. Barbara Harwas-Napierała wymienia w tym kontekście: osłabienie rangi wychowania, niedocenianie wychowania w rozwoju członków rodziny, coraz częstszą rezygnację $\mathrm{z}$ ingerowania w wychowanie, forsowanie nieograniczonego rozwoju, zmniejszenie roli autorytetu dorosłych członków rodziny, nacisk na samodzielność, osłabienie więzi rodzinnych, ignorowanie troski o dziecko lub też błędne zrównanie troski z nadopiekuńczością. Jednocześnie sama rodzina jest zagrożona przez: zmniejszającą się liczbę urodzeń, atomizację rodziny, wzrost liczby konfliktów w rodzinie, rozwodów

10 Marta Najder, „Zagrożenia współczesnej rodziny”, w: Rodzina a współczesność, red. Andrzej Ładyżyński (Wrocław: Wydawnictwo Oświatowe ATUT, 2009), 241-242.

${ }^{11}$ Anna Chmielewska, „Środowisko rodzinne jako źródło trudności i wsparcia”, w: Wielość spojrzeń na malżeństwo i rodzinę, red. Anna Kwak, Mariola Bieńko (Warszawa: Wydawnictwo Uniwersytetu Warszawskiego, 2012), 180. 
oraz rodzin zrekonstruowanych, pojawienie się alternatywnych form życia rodzinnego, rozpowszechnienie się blended families, czyli tak zwanych rodzin mieszanych, które składają się z dzieci z poprzednich związków ${ }^{12}$. Spada liczba zawieranych małżeństw, przybywa osób żyjących samotnie lub kolejno zawieranych związków małżeńskich (tzw. seryjna monogamia lub monogamia wielokrotna) $)^{13}$. Na szczególną uwagę zasługuje także zmiana warunków socjalizacji w rodzinie, co jest rezultatem umasowienia zatrudnienia kobiet $\mathrm{i}$ jednoczesnego obniżenia znaczenia ojca w rodzinie. Można sądzić, że ów efekt został jeszcze bardziej wzmocniony przez nastawienie wielu kobiet na osiagnięcie sukcesu zawodowego, kariery zawodowej oraz zatrudnienie rodziców poza miejscem zamieszkania. Coraz częściej oboje rodziców lub jedno pracuje dla firm czy instytucji wymagających dużej dyspozycyjności i mobilności pracowników. Ponadto ich centrale znajdują się często poza granicami województwa. W ten sposób przybywa rodzin niepełnych czasowo. Schemat rodziny niepełnej czasowo zaczyna być powielany przez kolejne pokolenia.

Trudno w tym kontekście nie przywołać poglądów obejmujących transmisję pokoleniową. Szczególnie dzieci wychowujące się w atmosferze dawania przywilejów osobie dorosłej bez akceptowania obowiązków przejmują wzór lansowany w rodzinie pochodzenia. Dzieci z rodzin rozbitych częściej powielają schemat własnych rodziców, co oznacza przejęcie struktury i formy życia rodzinnego ${ }^{14}$. Powielanie struktury rodziny niepełnej przez kolejne pokolenia nie jest dla pedagoga zaskoczeniem. Niepokojący może wydawać się fakt, że w niektórych rodzinach kolejne pokolenia doświadczają rozłąki dla zabezpieczenia potrzeb materialnych i w ten sposób tworzy się „łańcuch” rodzin rozłączonych.

Na skutek pojawienia się nowych czynników oddziałujących na rodzinę zmianie uległy pełnione przez nią funkcje. Zachwiana została także jej stabilność. Sytuacja ta jest jeszcze bardziej utrudniona przy braku jednego

12 Harwas-Napierała. „Rodzina jako wartość”, 12-16.

13 Zob. Franciszek Adamski, Rodzina. Wymiar społeczno-kulturowy (Kraków: Wydawnictwo Uniwersytetu Jagiellońskiego, 2002); Krystyna Slany, Alternatywne formy życia matżeńsko-rodzinnego w ponowoczesnym świecie (Kraków: Nomos, 2008); Rostowski, Rostowska, „Małżeństwo”, 229-242; Lucyna Bakiera, „Wartość małżeństwa w rozwoju człowieka dorosłego", w: Rodzina jako wartość w rozwoju człowieka, red. Barbara Harwas-Napierała (Poznań: Wydawnictwo Naukowe UAM, 2009), 25-57; Kwak, „Od i do małżeństwa”, 39-60; Monika Lewicka, Wybory życiowe studentów: matżeństwo - rodzina - formy alternatywne (Bydgoszcz: Wydawnictwo Uniwersytetu Kazimierza Wielkiego, 2014).

${ }^{14}$ Harwas-Napierała, „Rodzina jako wartość”, 19. 
z rodziców. Atmosferę bezpieczeństwa tworzą więzi międzyosobowe i emocjonalne. Więzi międzyosobowe są specyficznym złożonym układem stosunków łączących jednostki w grupę rodzinną poprzez przyznane czy przejawiane powinności i obowiązki względem każdej z osób. W tej atmosferze okazywana jest więź emocjonalna, czyli wyjątkowa relacja bliskości i ufności między członkami rodziny. Kolejną istotną kwestią jest spójność rodziny, która sprowadza się do podejmowania działań integrujących, prowadzących do wspólnotowego współodczuwania, zaangażowania w działania w rodzinie, wzajemną pomoc, wsparcie. Prawidłowy proces kształtowania się więzi między członkami rodziny sprzyja jej bezpieczeństwu, integralności i stanowi jednocześnie podstawę rozwoju każdego jej podmiotu. Wynika to z faktu, że rodzina posiada zdolności regulacyjne prowadzące do zachowania w niej równowagi. Utrzymywanie równowagi jest możliwe dzięki sprzężeniom zwrotnym, procesowi morfogenezy (inicjującej zmianę) i homeostazy. Homeostaza chroni rodzinę przed nadmiarem zewnętrznych bodźców i sprzyja zachowaniu stabilizacji. Utrzymuje zakorzenienie w tradycji, obyczajach, zachowuje tożsamość rodziny. Rodzina dzięki zdolnościom morfogenezy przejawia stałą tendencję do adaptacji, uzyskując tym samym równowagę ${ }^{15}$. Przykładem jest dostosowanie do zmian rozwojowych potomstwa, zmiany ról w rodzinie na skutek migracji. Czynniki zewnętrzne i wewnętrznie wpływają na rodzinę, lecz tylko od rodziny, utrzymywanych w niej więzi międzyosobniczych, emocjonalnych oraz spójności, będzie zależał kierunek zachodzących zmian.

Jednostka dzięki prawidłowym interakcjom wewnątrzrodzinnym zdobywa:

- doświadczenia stanowiące fundament kolejnych zmian rozwojowych;

- przyswaja sobie wzorce organizowania i interpretacji tego doświadczenia;

- uczy się zasad współczucia społecznego, norm moralnych;

- uczestniczy w interakcjach międzypokoleniowych, doświadczając problemów różnych faz rozwojowych;

- uczy się pełnienia funkcji społecznych;

- wchodzi w bliskie interakcje, ucząc się zasad wymiany psychicznej, otwartości oraz okazywania wsparcia dla innych i podlegania ich wpływom;

${ }^{15}$ Lucyna Bakiera, „Generatywność rodziców jako wartość rozwojowa”, w: Rodzina jako wartość w rozwoju człowieka, red. Barbara Harwas-Napierała (Poznań: Wydawnictwo Naukowe UAM, 2009), 64. 
- zdobywa ważne informacje będące podstawą do samookreślenia i samooceny ${ }^{16}$.

W sytuacji braku obecności jednego z rodziców następuje zmiana utrzymywania więzi poprzez bezpośredni kontakt, a więc jej spójność, integralność musi być wypracowywana w inny sposób.

\section{Rozumienie i rodzaje rodzin niepelnych czasowo ze względu na zatrudnienie}

Określenie rodziny niepełnej czasowo tylko pozornie wydaje się dość prostym zabiegiem. Zgodzić się można, że rodzina niepełna to ta, w której strukturze brak jednego rodzica. Zanim jednak przejdę do definicji rodziny niepełnej czasowo, przywołam pojęcie i rodzaj rozłąki. Rozłąka oznacza oddalenie się od siebie, brak możliwości bezpośredniej bliskości. Oddalenie się od siebie może nastąpić na skutek separacji, rozwodu, a w interesującym mnie zagadnieniu dotyczy wyjazdu poza miejsce zamieszkania rodziny. W literaturze wyróżnia się dwa modele rozłąki: model pulsacyjny i model rozłąki bezwzględnej. Model pulsacyjny jest skutkiem posiadania podwójnego obywatelstwa, co oznacza podejmowanie pracy za granicą. Charakterystyczną cechą jest cykliczne spotykanie się rodziny. Drugi model bezwzględnej rozłąki obejmuje wyjazd rodzica na inny kontynent i z tej racji bardzo rzadki kontakt bezpośredni, czyli przyjazd do kraju raz na kilka lat ${ }^{17}$. Ten podział obowiązuje także dzisiaj, chociaż kraj imigracji nie jest już tak istotny dla spotykania się z rodziną ze względu na nieograniczone możliwości komunikacyjne. Koncepcja fast car jest coraz bardziej dostępna dla każdego człowieka. Oczywiście najwięcej możliwości komunikacyjnych występuje na obszarze Unii Europejskiej. Bez względu na liczbę kontaktów proces

${ }^{16}$ Maria Tyszkowa, „Rozwój psychiczny jednostki jako proces strukturacji i restrukturacji doświadczenia", w: Rozwój psychiczny człowieka w ciagu życia. Zagadnienia teoretyczne i metodologiczne, red. Maria Tyszkowa (Warszawa: Wydawnictwo Naukowe PWN, 1988), 47-79; Maria Tyszkowa, „Rodzina, doświadczenie i rozwój jednostki”, w: Rodzina a rozwój jednostki, red. Maria Tyszkowa (Poznań: Nakładem Centralnego Programu Badań Podstawowych, 1990), 13-37; Maria Tyszkowa, ,Jednostka a rodzina: interakcje, stosunki, rozwój”, w: Psychologia rozwoju człowieka, red. Maria Przetacznik-Gierowska, Maria Tyszkowa (Warszawa: Wydawnictwo Naukowe PWN, 2000), 124-150, cyt. za: Bakiera, „Generatywność rodziców”, 63.

17 Anna Fidelus, „Gdy rodzice emigrują...”, Nowa Szkoła 6 (2008): 37. 
migracji obejmuje trzy etapy: etap podejmowania decyzji, etap uczestnictwa, etap „konsumpcji” efektów, czyli analizy zysków i strat migracji18.

Wyjazd jednego z rodziców prowadzi do ukonstytuowania się rodziny niepełnej. W literaturze $w$ tej sferze istnieje już określona jej periodyzacja. Zgodnie z nią do rodzin niepełnych zaliczamy rodziny osierocone na skutek śmierci współmałżonka; rozbite, które dzielą się na będące w separacji lub po rozwodzie; rodziny niepełne biologiczne, które oznaczają urodzenie dziecka pozamałżeńskiego oraz rodziny czasowo niepełne. Rodziny czasowo niepełne tworzą się ze względu na: charakter pracy, pobyt za granica, chorobę wymagająca dłuższego leczenia poza domem i pobyt w zakładzie karnym ${ }^{19}$.

W niniejszym artykule skoncentrowano się na rodzinie, która jest czasowo niepełna. Interesuje mnie nie tylko sytuacja dziecka, ale także małżonków żyjących w rozłące. Grupa tego typu rodzin jest wewnętrznie zróżnicowana. Wyróżniamy rodzinę niepełną czasowo ze względu na pobyt rodzica w szpitalu, w zakładzie penitencjarnym oraz wyjazdy migracyjne. Wioletta Danielewicz analizuje typy rodzin niepełnych ${ }^{20}$. Klasyfikacja rodzin niepełnych jest bardzo szczegółowa. Uwagę przykuwa typologia rodzin ze względu na nieobecność rodzica. I tak autorka wyróżnia: 1) rodziny niepełne czasowo z powodu wyjazdu jednego rodzica do pracy za granicę; 2) rodziny niepełne czasowo z powodu wyjazdu równocześnie obojga rodziców do pracy za granicę; 3) rodziny niepełne czasowo z powodu wyjazdu zamiennie rodziców; 4) rodziny stale niepełne przed wyjazdem rodzica za granicę; 5) rodziny niepełne stale ze względu na rozwód lub porzucenie w trakcie migracji.

Pierwszą kwestią jest odległość rodzica od współmałżonka z dzieckiem. Rodzic może podjąć pracę w innym województwie, na terenie Europy i na innym kontynencie. Bez względu na miejsce pracy następuje zerwanie relacji bezpośrednich ze współmałżonkiem i dzieckiem. Kontakty są utrzymywane dzięki technologii cyfrowej (e-maile, skype) oraz połączeniom telefonicznym. Częstotliwość i rodzaj kontaktów zależy nie tylko od możliwości

${ }_{18}$ Zofia Kawczyńska-Butrym, Migracje. Wybrane zagadnienia (Lublin: Wydawnictwo Uniwersytetu Marii Curie-Skłodowskiej, 2009), 115.

19 Julian Auleytner, Dorota Błaszczyk, „Problemy wychowawcze w rodzinach niepełnych”, w: Rodzina w okresie transformacji systemowej, red. Adam Kurzynowski (Warszawa: Wydawnictwo Wyższej Szkoły Pedagogicznej Towarzystwa Wiedzy Powszechnej, 1995), 180; Wioletta Danielewicz, Sytuacja życiowa dzieci w rodzinach migracyjnych (Białystok: Wydawnictwo Trans Humana, 2006), 99-100.

${ }^{20}$ Danielewicz, Sytuacja, 99-100. 
finansowych i technicznych, ale także od indywidualnych cech jednostek. Wskazywać można także na długość wyjazdu. Im dłuższy wyjazd, tym kontakty stają się coraz rzadsze.

Czas i częstotliwość wyjazdów to kolejne kryterium podziału rodzin niepełnych. Rodziny posiadają określoną stabilność, bowiem można dokładnie przewidzieć wyjazd, a także powrót współmałżonka. Są to wyjazdy w określonych cyklach czasowych związanych z charakterem pracy wykonywanej przez marynarzy, rybaków morskich, żołnierzy, geologów, posłów czy europosłów. Bardziej destabilizująca dla rodziny jest praca zawodowa wymagająca nieustannej mobilności i dużej liczby wyjazdów służbowych. Brak stałości oraz cykliczności występuje na przykład w firmach budowlach, transportowych, farmaceutycznych czy medycynie ${ }^{21}$. Również pracownicy naukowi są grupą zawodową, której dotyczą częste wyjazdy służbowe i nienormowany czas pracy.

W wykonywanie określonego zawodu zawsze jest wpisane ryzyko. Szczególnym zawodem jest służba w Polskich Siłach Zbrojnych. Od 1953 roku polscy żołnierze uczestniczą w misjach stabilizacyjnych i pokojowych. W latach 1953-2014 roku śmierć poniosło 126 żołnierzy. Dokładna liczba inwalidów i poszkodowanych nie jest znana. Zawód żołnierza wyjeżdżającego na misję można określić jako zawód wysokiego ryzyka, związanego z zagrożeniem życia i zdrowia. Ponadto na misję do Iraku oraz Afganistanu wyjeżdżali także psycholodzy, lekarze i specjaliści.

Istnieje specyfika problemów występujących $\mathrm{w}$ rodzinach $\mathrm{z}$ małym dzieckiem czy też z nastolatkiem. Rodzina jest miejscem nawiązywania kontaktów bezpośrednich ${ }^{22}$. Relacje między rodzicami i dziećmi mają inny charakter ze względu na ich wiek rozwojowy. Małe dziecko wymaga czułości, zabawy i opieki, starsze natomiast - zainteresowania, zrozumienia, współpracy i współdziałania. Wsparcie rodziców, ich zrozumienie i relacje bezpośrednie z dziećmi są ważne dla określenia przez nie tożsamości.

Staż małżeński jest ostatnim kryterium podziału rodzin niepełnych czasowo. Młodzi rodzice, często nieposiadający własnego mieszkania i satysfakcjonującej pracy zawodowej, decydują się na stały wyjazd. Wysoka ocena ekonomiczna oraz społeczno-wychowawcza miejsca, w którym zatrudniony jest jeden z rodziców, wpływa na podjęcie decyzji o zatrudnieniu. Trudniej

${ }^{21}$ Auleytner, Błaszczyk, „Problemy wychowawcze”, 185.

${ }^{22}$ Elżbieta Zubrzycka, Narzeczeństwo, matżeństwo, rodzina, rozwód? (Gdańsk: Gdańskie Wydawnictwo Psychologiczne, 1993), 151. 
podjąć taką decyzję małżonkom z dłuższym stażem małżeńskim, posiadającym zaplecze w postaci mieszkania i dobrej pracy drugiego rodzica.

Przyjmując przedstawione kryteria, można podjąć próbę wyróżnienia rodzajów rodzin czasowo niepełnych ze względu na zatrudnienie jednego z rodziców. Jest to tylko propozycja, bowiem problem rodzin niepełnych czasowo ze względu na zatrudnienie jest wielopłaszczyznowy. Kryteria podziału i rodzaje są następujące:

\section{1) Terytorium zatrudnienia rodzica:}

a) zatrudnienie rodzica poza miejscem zamieszkania, ale w kraju;

b) zatrudnienie rodzica za granica:

- wyjazdy do krajów Unii Europejskiej,

- wyjazdy do krajów poza Unię.

2) Wykonywanie zawodu ze względu na ryzyko:

a) zawód wysokiego ryzyka, związany z zagrożeniem życia i zdrowia (misje stabilizacyjne);

b) zawód wykonywany bez atmosfery zagrożenia życia.

3) Czas i częstotliwość wyjazdów:

a) wyjazdy do pracy w określonych cyklach czasowych (praca zawodowa marynarzy, rybaków morskich, żołnierzy, posłów, europosłów);

b) praca związana z wymaganiem nieustannej mobilności, duża liczba wyjazdów w delegacje, brak stałości i cykliczności (pracownicy firm budowlanych, transportowych, farmaceutycznych, pracownicy naukowi).

4) Wiek dziecka - zgodnie z okresem rozwojowym:

a) wczesne dzieciństwo - pierwszy rok życia,

b) wczesne dzieciństwo - drugi i trzeci rok życia,

c) wiek przedszkolny,

d) wiek szkolny,

e) okres dorastania ${ }^{23}$.

5) Staż malżeński:

a) rodziny do 3 lat stażu,

b) 4-9 lat stażu,

c) 10-25 lat stażu,

d) 26 lat i powyżejej ${ }^{24}$.

${ }^{23}$ Psychologiczne portrety człowieka, red. Anna Izabela Brzecińska (Gdańsk: Gdańskie Wydawnictwo Psychologiczne, 2005).

${ }^{24}$ Mariola Bieńko, „Współczesne skrypty bycia razem. Zamierzony i realizowany pro- 
Przedstawiona periodyzacja ujawnia wielowarstwowość problematyki rodzin niepełnych czasowo ze względu na zatrudnienie poza miejscem zamieszkania. Rodziny niepełne czasowo z punktu widzenia prawa są rodzinami pełnymi. Wyjazd jednego z rodziców tworzy nową sytuację w rodzinie ${ }^{25}$. Badania przeprowadzone wśród marynarzy pozwoliły na sprecyzowanie kilku wniosków. Zostały wyodrębnione trzy okresy charakterystyczne dla rodzin czasowo niepełnych ze względu na zatrudnienie. Pierwszy obejmuje czas oczekiwania na przyjazd rodzica. Rodzic pozostający w kraju wykonuje wszystkie obowiązki w celu spędzania czasu wolnego z nieobecnym rodzicem po jego powrocie. Drugi etap to przyjazd nieobecnego rodzica charakteryzujący się koncentracją na relacjach. Życie w rodzinie skupia się wokół spędzania czasu wolnego z nieobecnym rodzicem oraz podejmowania ważnych decyzji. Występuje poczucie zadowolenia, bezpieczeństwa. Ostatni, trzeci okres obejmuje przystosowanie do rozstania ${ }^{26}$. Etap nieobecności rodzica charakteryzuje się tęsknota, poczuciem osamotnienia i obarczeniem pozostającego rodzica, jak też dzieci zwiększonymi obowiązkami. Scharakteryzowane rodziny marynarzy i rybaków wskazują na kształtowanie się wśród tej grupy matrycentrycznego modelu rodziny oraz specyficznego podziału obowiązków. Z uwagi na wysokie dochody rodziny wypełniają funkcje materialno-ekonomiczne, socjalizacyjno-wychowawcze, kulturalne, emocjonalno-ekspresyjne w wysokim stopniu ${ }^{27}$.

\section{Przyczyny i skutki rozłąki w rodzinach czasowo niepelnych}

Najczęściej Polacy decydują się na migrację ze względów ekonomicznych. Zofia Kawczyńska-Butrym ${ }^{28}$ wskazuje na wyjazdy jednego z rodziców będącego w średnim wieku i z relatywnie niższym wykształceniem, co

jekt scenariuszy ról małżeńskich", Młodzież a rodzina. Roczniki Socjologii Rodziny XIX (2008-2009), 77.

${ }^{25}$ Edyta Mituła, „Rodziny pełne nie w pełni - eurosieroctwo. Opieka nad dzieckiem a migracja zarobkowa rodziców", w: Rodzina a współczesność, red. Andrzej Ładyżyński (Wrocław: Wydawnictwo Oświatowe ATUT, 2009), 166.

${ }_{26}$ Małgorzata Fojcik, „Dziecko a migracja zarobkowa rodziców”, Życie Szkoły 7 (2007): 14.

27 Wioletta Danielewicz, „Zagrożenia realizacji funkcji rodziny”, w: Pomoc dziecku i rodzinie w środowisku lokalnym, red. Wioletta Danielewicz, Jadwiga Izdebska, Beata Krzesińska-Żach (Białystok: Wydawnictwo Trans Humana, 1999).

${ }^{28}$ Kawczyńska-Butrym, Migracje. 
nazywa tak zwaną „migracją przeżycia”. Bożena Matyjas ${ }^{29}$ pisze o migracji przetrwania. Jest to grupa rodzin z problemami bytowymi, charakteryzujących się niskimi zarobkami i trudnościami w zatrudnieniu się ${ }^{30}$. Zatem pierwszą oraz najczęstszą przyczyną jest brak pracy w kraju. Drugą bardzo ważną jest dążenie do poprawy jakości życia rodziny. Jednocześnie wystąpić może także sytuacja, w której rodzic uzależniony od alkoholu, konfliktogenny lub brak prawidłowych relacji między rodzicami stają się przyczyną zatrudnienia poza miejscem zamieszkania rodziny ${ }^{31}$. Na przyczyny wyjazdów natury psychologicznej wskazują także inni autorzy. Brak bliskiej więzi w małżeństwie, brak rozmów, wzajemne rozczarowanie, nieumiejętność budowania stałej i silnej relacji, tkwienie w nierozwiązanych kryzysach, błędnym kole wzajemnych oskarżeń prowadzi do opuszczenia domu ${ }^{32}$. Wyróżniono pozytywne, jak również negatywne skutki migracji zarobkowej. Do pozytywnych skutków zalicza się: poprawę zamożności rodzin, wzrost konsumpcji, wzrost wydatków inwestycyjnych, efekt modernizacyjny rodzin odzwierciedlony w podwyższeniu kompetencji kulturowych i zawodowych osób migrujących. Natomiast negatywne skutki migracji obejmują: deformację struktury demograficznej, zmniejszenie potencjału prokreacyjnego i produkcyjnego społeczeństwa na skutek wyjazdu osób młodych, dobrze wykształconych, wpływ na funkcjonowanie rodzin pozbawionych kontaktów z rodzicem ${ }^{33}$. Wioleta Danielewicz wyróżnia trzy obszary negatywnych skutków migracji, do których zalicza: brak wzoru osobowego rodzica nieobecnego w rodzinie, co może być powodem błędnego interpretowania jego roli; zagrożenie wypełnienia funkcji socjopsychologicznej, którego podłożem jest zła sytuacja ekonomiczna rodziny; niedostateczną opiekę spowodowaną brakiem czasu dla dzieci. Zbyt duże obciążenie jednego z rodziców obowiązkami zawodowymi prowadzi do braku utrzymywania relacji z dzieckiem lub dziećmi. Występuje w tej sytuacji zachwianie realizacji funkcji społeczno-wyznaczającej

29 Bożena Matyjas, Dzieciństwo w kryzysie: etiologia zjawiska (Warszawa: Wydawnictwo Akademickie Żak, 2008).

${ }^{30}$ Kawczyńska-Butrym, Migracje.

31 Danielewicz, „Zagrożenia realizacji”, 71.

32 Barbara Smolińska, „Tata na emigracji”, Charaktery 7 (2008): 76; Krzysztof Głowiak, „Wyjazdy zagraniczne zagrożeniem funkcjonowania rodzin”, Problemy Opiekuńczo-Wychowawcze 5 (2012): 57.

${ }^{33}$ Bożena Kołaczek, „Sytuacja społeczna i ekonomiczna rodzin niepełnych w Polsce”, w: Samotne rodzicielstwo a zagrożenie wykluczeniem społecznym, red. Bożena Balcerzak-Paradowska (Warszawa: Instytut Pracy i Spraw Socjalnych, 2014), 46. 
i socjopsychologicznej ${ }^{34}$. Z badań Bożeny Balcerzak-Paradowskiej ${ }^{35}$ wyni$\mathrm{ka}$, że w rodzinach czasowo rozłączonych, głównie z powodu nieobecności jednego z rodziców (czemu towarzyszy nadmierne obciążenie rodzica, który pozostał, z niewystarczającą ilością czasu dla dziecka), występują częściej i z większym nasileniem problemy wychowawcze. Sytuacja rodzin niepełnych jest więc złożona, często wielowarstwowa. Z rozważań wynika, że niepełność może być przyczyną zagrożenia realizacji funkcji rodziny tylko w określonych sytuacjach. Nie musi zostać zachwiana stabilność rodziny, a nawet może nastąpić jej powrót do równowagi i bezpieczeństwa. Istotne jest zwrócenie uwagi na obszary, które mogą zagrażać rodzinie niepełnej.

Wzrost liczby rodzin niepełnych ze względu na zatrudnienie spowodował zainteresowanie się funkcjonowaniem tych rodzin. W literaturze prowadzona jest dyskusja dotycząca dzieci w rodzinach niepełnych, którym nadano nazwę eurosierot. Polemizowałabym z traktowaniem wszystkich dzieci, których jedno z rodziców wyjechało ze względów zawodowych, jako eurosieroty. Bowiem czy dziecko marynarza, rybaka handlowego, żołnierza, inżyniera budowlanego można traktować jako sierotę? Sylwia Urbańska wskazuje jeszcze na posła przebywającego większość tygodnia w hotelu poselskim czy też europosła będącego jeszcze dalej od rodziny ${ }^{36}$. Czy można sieroctwo mierzyć kilometrami dzielącymi rodzica od dzieci? „Eurosieroctwo” oznacza dla Ewy Zawisza-Masłyk ,czasowe pozostawienie dziecka w kraju, pod opieką dorosłych osób trzecich [...] spowodowane przez wyjazd obojga rodziców za granicę (na terenie Europy) w celach zarobkowych z zachowaniem utrzymywania z dzieckiem stałych kontaktów"37. Zjawisko to nie zawsze oznacza wyjazd obojga rodziców, czasem jest ograniczone do wyjazdu jednego rodzica. Dyskusyjne jest wprowadzenie terytorialności w definiowaniu. Ograniczenie zjawiska „eurosieroctwa” tylko do Europy jest zasadne z uwagi na przyrostek ,euro”. Autorka zwraca uwagę także na wyróżnienie sytuacji, w których tylko jeden z rodziców wyjeżdża w celach zarobkowych poza miejsce zamieszkania. Takie okoliczności proponuje nazwać „euro-półsieroctwem". Jednocześnie podkreśla, że ze względów lingwistycznych nie

34 Danielewicz, „Zagrożenia realizacji”, 71.

${ }^{35}$ Bożena Balcerzak-Paradowska, „Wpływ okresowej migracji na warunki życia rodziny”, Problemy Rodziny 5 (1994): 11-14.

${ }^{36}$ Sylwia Urbańska, „«Cała Polska liczy eurosieroty». Panika moralna i płeć w wykluczeniu oraz stygmatyzacji rodzin migrantów", Kultura i Społeczeństwo 3 (2010): 75.

37 Ewa Zawisza-Masłyk, „Wokół pojęcia «eurosieroctwo»”, Opieka, Wychowanie, Terapia 3-4 (2008): 41. 
jest to szczęśliwe określenie. Zauważać należy, że pojęcie „eurosieroctwa” i ,euro-półsieroctwa” koncentruje się na dziecku, jego sytuacji społecznej, ekonomicznej, wychowawczej i psychologicznej. W tym kontekście jest opisywane w literaturze. Niemniej funkcjonuje jeszcze pojęcie ,sieroctwo migracyjne". Nie ma miejsca w artykule na rozwinięcie wątku zatrudnienia rodzica zgodnie z wykształceniem, jego sytuacji w kraju zatrudnienia, rozwoju zawodowego, który może być zróżnicowany i zależny od wielu czynników. Jest to także ważne zagadnienie, bowiem dyspozycyjność oraz mobilność jest wpisana w wykonywanie coraz większej liczby zawodów.

Nieobecność jednego z rodziców ma psychologiczne skutki dla rozwoju emocjonalnego i społecznego dzieci. Mogą one być pozytywne i negatywne. Będzie wpływała na to częstotliwość kontaktu z rodzicem, który przebywa na emigracji. Pozostające $w$ kraju dzieci różnie sobie radzą z kryzysami normatywnymi i nienormatywnymi w rodzinie. James L. Greenstone i Sharon C. Leviton wymieniają reakcje na kryzys dzieci ze względu na ich wiek.

Tabela 1. Reakcje dzieci na kryzys według J. L. Greenstone'a i S. C. Leviton

\begin{tabular}{|c|l|}
\hline Wiek & \multicolumn{1}{|c|}{ Reakcje } \\
\hline $1-5$ lat & $\begin{array}{l}\text { Ssanie kciuka, nocne moczenie, lęk przed ciemnością lub zwierzętami, } \\
\text { koszmary senne, trudności w mówieniu, brak apetytu lub nadmierny } \\
\text { apetyt, lęk przez pozostawieniem w samotności, bezruch. }\end{array}$ \\
\hline 5-11 lat & $\begin{array}{l}\text { Drażliwość, płaczliwość, agresywne zachowania, niechęć do szkoły, } \\
\text { kłopoty z koncentracją, lęk przed doznaniem krzywdy, lęk przed po- } \\
\text { rzuceniem, dezorientacja, ogólny niepokój. }\end{array}$ \\
\hline $11-14$ lat & $\begin{array}{l}\text { Zakłócenia snu, zaburzenia apetytu, buntownicze zachowania w domu, } \\
\text { odmowa wykonywania obowiązków, problemy w szkole, problemy } \\
\text { fizyczne, utrata zainteresowania zajęciami rówieśników, lęk przed } \\
\text { utratą członków rodziny, przyjaciół, domu, ogólny niepokój. }\end{array}$ \\
\hline $14-18$ lat & $\begin{array}{l}\text { Objawy psychosomatyczne (wysypka, problemy z trawieniem, bóle } \\
\text { głowy, astma), zaburzenia menstruacyjne, pobudzenie lub spadek po- } \\
\text { ziomu energii, spadek zainteresowania płcią przeciwna, zachowanie } \\
\text { nieodpowiedzialne, przestępcze, kłopoty z koncentracją, gniew na } \\
\text { niesprawiedliwość losu, który przyniósł kryzys, tendencja do obwi- } \\
\text { niania innych za negatywne wydarzenia. }\end{array}$ \\
\hline
\end{tabular}

Źródło: Anita Rawa-Kochanowska, „Obraz rodziny u «sierot emigracyjnych»”, w: Rodzina w sieci wartości. Religia, praca i czas wolny, red. Wojciech Muszyński (Toruń: Wydawnictwo Adam Marszałek, 2010), 311-312. 
Anita Rawa-Kochanowska w wyniku przeprowadzonych badań stwierdziła, że obraz rodziny niepełnej czasowo jest pozytywny. Komunikacja w rodzinie jest prawidłowa, emocje członków rodziny są łatwe do odczytania. Relacje są nastawione na kontakt i bliskość. Na uwagę zasługuje fakt pewnego osłabienia więzi w rodzinie ze względu na brak współdziałania. Występuje także przemieszanie się ról. Badania opisują również wyraźnie pojawiające się wskaźniki podwyższonego niepokoju, co może świadczyć o pojawianiu się problemów emocjonalnych, jako reakcji na sytuację stresową. Sytuacją stresową jest w tym wypadku wyjazd rodzica za granicę ${ }^{38}$. Nie zawsze można wymieniać tylko negatywne skutki wyjazdów. Dlatego też problem jest złożony. Interesujące byłoby określenie, w jakich sytuacjach możemy wyrokować o pozytywnych skutkach wyjazdów, a kiedy o negatywnych. Niemniej przeprowadzone liczne badania wskazują na następujące skutki negatywne występujące w rodzinach niepełnych czasowo. Są one następujące:

- zaniedbanie emocjonalne dzieci;

- poczucie osamotnienia, przygnębienia, niepokój, lęki;

- zmniejszenie ilości czasu wolnego;

- rozpad co trzeciego małżeństwa;

- pogorszenie relacji wewnątrzmałżeńskich między dorosłymi oraz dorosłymi i dziećmi;

- pogorszenie atmosfery $\mathrm{w}$ rodzinie;

- deprywacja potrzeb seksualnych;

- przeciążenie obowiązkami pozostałego współmałżonka;

- zmiana pełnionych ról społecznych i rodzinnych oraz charakter stosunków interpersonalnych;

- brak pełnego wzoru ról rodzicielskich;

- problemy z zachowaniem dzieci;

- powrót rodzica do domu powoduje zmianę ustalonego cyklu życia, co oznacza przejęcie obowiązków i prowadzi do sytuacji stresowych, konfliktów ${ }^{39}$.

38 Anita Rawa-Kochanowska, „Obraz rodziny u «sierot emigracyjnych»”, w: Rodzina w sieci wartości. Religia, praca i czas wolny, red. Wojciech Muszyński (Toruń: Wydawnictwo Adam Marszałek, 2010), 318.

39 Zob.: Zawisza-Masłyk, „Wokół pojęcia”, 40-42; Mituła, „,Rodziny pełne”, 163-183; Wioletta Danielewicz, „Problemy rodzin czasowo niepełnych ze względu na długotrwały pobyt rodziców za granicą", w: Pedagogika społeczna jako dyscyplina naukowa. Stan i perspektywy, red. Ewa Marynowicz-Hetka, Jacek Piekarski, Ewa Cyrańska (Łódź: Wydawnictwo Uniwersytetu Łódzkiego, 1998), 289-295; Fojcik, „Dziecko”, 12-15; Smolińska, „Tata”, 
Paradoksalne jest to, że dłuższa nieobecność rodzica jest lepsza niż wielokrotne wyjazdy i powroty. Brak cykliczności oraz krótkotrwałość wyjazdów powoduje liczne sytuacje traumatyzujące. Rodzina po powrocie rodzica musi dostosować się do połączenia, a potem szybko przystosować do rozłąki. Jest w nieustannym akcie tworzenia rodziny pełnej i niepełnej. Charakteryzuje ją niepewność czy nieustanna zmiana ról, zmieniają się zadania, oczekiwania

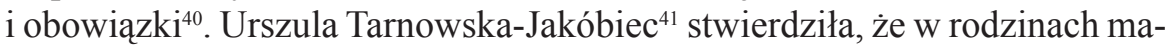
rynarzy, rybaków występuje duże oddziaływanie na realizację funkcji socjalizacyjnej i wychowawczej. Konsekwencje wyjazdów wpływają na rozwój dzieci, który przejawia się w zakłóceniu pełnienia roli społecznej i nawiązywania relacji z płcią przeciwną w okresie dorastania ${ }^{42}$. Rodzina ludzi morza w opinii Ludwika Janiszewskiego jest:

1. rodziną chronicznie rozłączoną, rodzice i dzieci są związani z krótszą bądź dłuższą nieobecnością jednego ze współmałżonków;

2. rodziną o specyficznym cyklicznym charakterze życia rodzinnego;

3. rodziną matrycentryczną, ponieważ najważniejszą osobą jest matka, wokół której koncertuje się przebieg życia rodzinnego;

4. rodziną zdezorganizowaną na skutek zmiany struktury i funkcji;

5. rodziną zamknięta, o charakterze domocentrycznym, ale w pełni autonomiczną i uniezależnioną od wpływów zewnętrznych;

76-77; Ewa Kozdrowicz, „Psychospołeczne skutki rozłąki migracyjnej”, w: Szkoła wobec mobilności zawodowej rodziców i opiekunów, red. Ewa Kozdrowicz, Bartłomiej Walczak (Warszawa: Centrum Metodyczne Pomocy Psychologiczno-Pedagogicznej, 2008), 21-37; Grażyna Miłkowska, Anna Kulesza, „Wpływ emigracji zarobkowej rodziców na funkcjonowanie dzieci w rodzinie i szkole", Problemy Opiekuńczo-Wychowawcze 9 (2009): 3-15; Andrzej Grudziński, „Funkcjonowanie rodziny w kontekście migracji zarobkowej zarys problemu”, w: Senior i rodzina, red. Marek Banach, Adam Szwedzik (Kraków: Biblioteka Instytutu Pracy Socjalnej Uniwersytetu Pedagogicznego im. Komisji Edukacji Narodowej w Krakowie, 2013), 161-170; Walczak, „Wychowawcze i edukacyjne konsekwencje”, 21-26; Ludwik Janiszewski, Rodzina marynarzy i rybaków morskich (Warszawa-Poznań: PWN, 1976), 233-234; Danielewicz, „Zagrożenia realizacji”; Anna Winiarczyk, „Migracje zarobkowe jedną z przyczyn niepełności rodziny”, Pedagogika Rodziny 1 (2011): 71-80; Agnieszka Sadowska, „Migracja rodziców źródłem dysfunkcjonalności środowiska wychowawczego dziecka", w: Zagrożenia i problemy współczesnej rodziny, red. Sylwester Bębas (Radom: Wydawnictwo Wyższej Szkoły Handlowej, 2011), 37-47.

${ }^{40}$ Urszula Tarnowska-Jakóbiec, Rodziny marynarzy i rybaków dalekomorskich jako środowisko wychowawcze, Szczecin 1998, 105; Mituła, „Rodziny pełne”, 174-175.

41 Tarnowska-Jakóbiec, Rodziny marynarzy, 30.

${ }^{42}$ Urszula Tarnowska-Jakóbiec, „Warunki rozwoju dzieci i młodzieży w rodzinie ludzi morza", w: Współczesne rodziny polskie w okresie radykalnych zmian społecznych, red. Ludwik Janiszewski (Szczecin: Wydawnictwo Uniwersytetu Szczecińskiego, 1998), 236-237. 
6. rodziną o silnej więzi wewnętrznej - członkowie rodziny są świadomi zagrożeń wynikających z trudności przystosowawczych oraz lęku przed dezintegracją rodziny ${ }^{43}$.

Z badań przeprowadzonych przez Ryszarda Dyoniziaka w latach 1982$-1984^{44}$ wynika, że nieobecny rodzic ma wpływ na zachowanie dzieci. Jego pozycję zwiększa wsparcie materialne. Osłabienie rodziny jest związane z procesem decyzyjnym, który przysługuje najczęściej matce. To rodzic pozostający z dzieckiem rozwiązuje bieżące problemy. Mniejsze dzieci są bardziej związane z rodzicem, który na co dzień nawiązuje z nimi relacje. Natomiast dzieci w okresie adolescencji często szukają wsparcia wśród rówieśników. Jest to też związane z ich okresem rozwojowym, a zatem można podkreślić, że wpływ ten może być w ich sytuacji znaczniejszy niż u pozostałych uczniów. Ważna jest też długość wyjazdów. Im dłuższy wyjazd, tym większa dezorganizacja więzi rodzinnych. Krótkie wyjazdy nie niosą według autora istotnych negatywnych skutków. Opinie na temat wpływu czasu nieobecności są jednak podzielone. Zgodnie ze stanowiskiem Ludwika Janiszewskiego rozłąka trwająca długo może przyczynić się do negatywnych skutków w sferze fizjologicznej, psychicznej i społecznej równowagi w rodzinie $^{45}$. Anna Fidelus zwraca uwagę na zachowanie dzieci pozostawionych przez emigrujących rodziców. Wśród tej grupy dzieci zarówno w wieku przedszkolnym, młodszym wieku szkolnym czy też w okresie adolescencji mogą wystąić przejawy nieakceptowania norm społeczno-moralnych. Ich częstotliwość i natężenie są różne w zależności od wielu uwarunkowań związanych z migracją rodzica ${ }^{46}$. U dzieci mogą wystąpić zaburzenia typu eksternalizacyjnego (zachowanie wrogie, wycofanie $\mathrm{z}$ interakcji, smutek, obojętność, lęk) i internalizacyjnego (zachowania autodestrukcyjne, samookaleczenia, samobójstwa). Inny podział skutków wyjazdu do pracy obejmuje grupę konsekwencji psychologicznych (problemy z poczuciem własnej przynależności, brakiem poczucia bezpieczeństwa w relacjach, brakiem poczucia bliskości) i konsekwencji pedagogicznych (pogorszenie wyników w nauce, trudności z przestrzeganiem norm społeczno-moralnych ${ }^{47}$. $\mathrm{W}$ rodzinach czasowo niepełnych mogą wystąpić zaburzenia przywiązania

43 Janiszewski, Rodzina marynarzy, 72-331.

${ }^{44}$ Ryszard Dyoniziak, Sytuacja psychospołeczna rodzin, w których główni żywiciele przebywaja okresowo za granica (Kraków: Akademia Ekonomiczna, 1988).

45 Janiszewski, Rodzina marynarzy, 115.

${ }^{46}$ Fidelus, „Gdy rodzice”, 39.

47 Grudziński, „Funkcjonowanie rodziny”, 167. 
w dzieciństwie, zaburzenia zachowania, zaburzenia emocjonalne i depresyjne. „Istotny jest fakt, iż wystapienie zaburzenia należy rozważać w aspekcie połączenia predyspozycji intrapsychicznych, jakości więzi przed wyjazdem osoby znaczącej oraz dostępności i umiejętności czerpania $\mathrm{z}$ dostępnego wsparcia. Sam fakt nieobecności rodzica/rodziców nie jest jednoznaczny z występowaniem trudności"48.

Mimo że w literaturze najwięcej jest wskazań obejmujących negatywne skutki emigracji rodziców, to wyróżnić można także w niektórych sytuacjach jej pozytywne efekty, na przykład: materialne (kupno mieszkania, samochodu, spłata kredytu), poznawcze (poznanie innego kraju), zdobycie umiejętności językowych ${ }^{49}$. Czasami wyjazd wywołuje refleksje małżonków na temat rodziny, dzięki czemu dostrzegają jej wartość, co w efekcie przyczynia się do jej umocnienia ${ }^{50}$. Rodzina zyskuje również w sytuacji wyjazdu rodzica uzależnionego.

\section{Rodziny czasowo niepelne żołnierzy wyjeżdżających na misje stabilizacyjne}

Praca żołnierzy poza granicami kraju wpływa na funkcjonowanie ich rodzin w trakcie wyjazdu oraz po powrocie. Żołnierze, narażając własne życie, odnoszą rany, w wyniku których mogą stać się inwalidami. Nie można zapominać także o niewidocznych zranieniach. Liczba żołnierzy rannych oraz z pourazowym stresem bojowym nie jest znana. Stanisław Ilnicki z Kliniki Psychiatrii i Stresu Bojowego Wojskowego Instytutu Medycznego w Warszawie stwierdza, że „brak jest rzetelnych statystyk, ilu żołnierzy straciło zdrowie wskutek traumy psychicznej. $Z$ wycinkowych badań sondażowych wynika, że u około 10 procent weteranów polskich kontyngentów wojskowych występują objawy niepełnego lub rozwiniętego zespołu stresu potraumatycznego"51. Żony żołnierzy wyrażają opinię, że również u nich

48 Marta Nowak, Agnieszka Gawęda, Małgorzata Janas-Kozik, „Zjawisko eurosieroctwa a kierunki pracy terapeutycznej i leczenia psychiatrycznego - prezentacja przypadku", Psychiatria Polska 2 (2012): 299.

49 Miłkowska, Kulesza, „Wpływ emigracji”, 3.

50 Tamże, 6.

51 Magdalena Rigamonti, „Niewidoczne rany. Wywiad z S. Ilnickim”, Newsweek, 1.03.2012, źródło: http://spoleczenstwo.newsweek.pl/niewidoczne-rany,88754,1,1.html [dostęp: 19.01.2013 r.]. 
występuje Zespół Stresu Pourazowego (PTSD), bo życie ze straumatyzowanym człowiekiem jest bardzo trudne. Zdarza się, że żony żołnierzy powracających z misji także trafiają na leczenie do kliniki Ilnickiego. Przeprowadzone badania obejmowały opinie o występowaniu przypadków patologii czy rozwodów. Zdaniem co dziesiątego respondenta rozwód występuje często $(12 \%-2010$ r., $18 \%$ - 2011 r.), co drugi sądzi, że sytuacja ta jest sporadyczna $(52 \%-2010$ r., $57 \%$ - 2011 r.), a co trzeci nie zauważył, aby takie sytuacje wystapiły. Podkreślane jest nadużywanie alkoholu $-6 \%$ badanych w 2010 roku i 13\% w 2011 r. uważa, że jest to częste zjawisko, odpowiednio 37\% i 31\% uznaje je za sporadyczne, a 57\% i 56\% stwierdza, że nie ma wiedzy na ten temat. Do nadużywania alkoholu przyznało się w 2010 roku $8 \%{ }^{52}$, a w 2011 r. $-13 \%$ badanych $^{53}$. Podobnie jest z opinią dotyczącą pogorszenia atmosfery i relacji w rodzinie. W 2010 roku 5\% żołnierzy, a w 2011 roku $10 \%$ uważało tę sytuację za występującą często, za sporadyczną uznało ją odpowiednio $37 \%$ i $43 \%$, a nie znało jej $57 \%$ i $48 \%$. Drastyczne naruszenie obowiązujących norm wystapiło zdaniem 9\% respondentów z 2011 roku często, a zdaniem 31\% - sporadycznie. Dodatkowa analiza ukazała, że 13\% (2010 r.) i 9\% (2011 r.) żołnierzy miało problem z nawiązaniem relacji w rodzinie. Problemy rodzinne występują częściej wśród żołnierzy powracających z Iraku i Afganistanu. Zdarzały się one na ogół u osób narażonych na występowanie silnego stresu podczas wykonywania obowiązków służbowych w czasie misji. Podobnie jest z nadużywaniem alkoholu, bowiem zjawisko to pojawiało się częściej u badanych, którzy doświadczali silnego stresu $^{54}$. Badanie z 2011 roku wykazało, że żołnierze nadużywający alkoholu częściej uczestniczyli w wymianie ognia. Pod wpływem rozłąki z rodziną dochodzi w mniejszym lub większym stopniu do zmian w zachowaniu jednego lub obojga rodziców. Życie z żołnierzem, jak twierdzą żony, nie jest łatwe. Towarzyszy mu osamotnienie, lęki o zdrowie i życie, uzależnienia, tęsknota, stres i PTSD. Następują także zmiany w osobowości dziecka, które tęskni oraz - w zależności od wieku - przeżywa dramat rozstania. Zachodzą także zmiany w rodzinie. Występują trudności w nawiązywaniu relacji, przystosowaniu do życia w domu.

${ }^{52}$ Zdrowotne i psychospołeczne skutki udzialu żolnierzy WP w misjach poza granicami kraju, oprac. Marian Kloczkowski, Łukasz Kiciński (Warszawa: Wojskowe Biuro Badań Społecznych, 2010), 4-25.

${ }^{53}$ Michał Iwanek, Readaptacja żotnierzy powracajacych z misji wojskowych poza granicami państwa (Warszawa: Wojskowe Biuro Badań Społecznych, 2011).

${ }^{54}$ Zdrowotne i psychospoleczne skutki. 
Rodziny żołnierzy wyjeżdżających na misje są narażone nie tylko na stres związany z samą rozłąka, ale także z zagrożeniem ich życia i zdrowia. Zagrożenie życia i zdrowia dotyczy także personelu medycznego czy psychologów wyjeżdżających na misje stabilizacyjne. Narażeni są także korespondenci wojenni, zdobywający materiały dla mediów. Zagrożenie życia i zdrowia jest związane z PTSD - stresem potraumatycznym, który dotyczy nie tylko osoby, która była w sytuacji zagrożenia, ale obejmuje także rodzinę. Jest to istotny problem obecnie podejmowany w literaturze. Młodzi mężczyźni wracający z Iraku czy Afganistanu nie potrafią rozwiązać swoich problemów. Meczą ich wspomnienia scen gwałtu, zabijania, deprecjonowania wartości męskiej przyjaźni. Ale walczy także kobieta, przyjaciółka, żona, matka ${ }^{55}$. Żony wychowujące dzieci i przeżywające jednocześnie dramat rozstania z mężem oraz troski o jego życie, borykają się z poważnymi problemami, a sytuacja, w jakiej się znajdują, bywa dla nich bardzo wyczerpująca.

\section{Zakończenie}

Podjęte rozważania opisują rodzinę czasowo niepełną. Niepełność wynika z zatrudnienia rodzica poza miejscem zamieszkania. Sytuacja ta, początkowo spotykana tylko wśród marynarzy, rybaków dalekomorskich i żołnierzy, rozszerzyła się na inne liczne zawody. Nowoczesny świat umożliwił szybkie przemieszczanie się ludzi, co zostało wykorzystane nie tylko w branży turystycznej, ale także w dziedzinie zatrudnienia. Ludzie w różnym wieku poszukują pracy zawodowej poza granicami kraju, ale także w innym województwie. Pojawienie się wielu nowych możliwości podjęcia pracy doprowadziło do wyróżnienia rodzin niepełnych czasowo ze względu na pięć kryteriów: terytorium zatrudnienia, zawód wysokiego ryzyka, czas i częstotliwość wyjazdów, wiek dziecka oraz staż małżeński. Duża mobilność rodziców lub wyjazdy któregoś z członków rodziny coraz częściej stają się jedną z cech współczesnej rodziny. Zauważyć należy, że częste i długie podróże wpływają niekorzystnie na funkcjonowanie rodziny.

W rodzinach następuje zmiana ról rodzicielskich, rozluźnienie więzi, zakłócenia komunikacji między podmiotami, mogą wystąpić zaburzenia psychonerwowe, uzależnienia, niekorzystne zachowanie dzieci oraz brak osiągnięć edukacyjnych. Nieobecność jednego z rodziców powoduje, że utrzymywanie więzi poprzez bezpośredni kontakt zmienia się na pośredni, reali-

55 Ryszard Romaniuk, „Porada”, Niebieska Linia 4 (2009): 32. 
zowany dzięki technologii cyfrowej. Spójność, integralność rodziny musi być zatem wypracowywana w zupełnie inny sposób.

Wyjazdy jednego z rodziców nie muszą negatywnie wpływać na rodzinę. Najważniejszym warunkiem ,przetrwania” rozłąki jest silna, realna więź między członkami rodziny. Rodziny muszą dbać o wysoką jakość życia rodzinnego, która jest efektem odgrywania ról społecznych oraz sposobów ich przejawiania ${ }^{56}$. Wspólna decyzja małżonków oraz zgoda na wyjazd i rozłąkę, ustalenie specyfiki wyjazdu, obowiązków czy komunikacji będą sprzyjały prawidłowym relacjom w rodzinie. Relacje powinny być podtrzymywane przez różnorodne formy kontaktu: SMS-y, skype'a, rozmowy telefoniczne, e-maile ${ }^{57}$. Częstotliwość kontaktów musi być duża, regularna i niezmienna, bowiem to one podtrzymują zainteresowanie problemami, wspólną radość z sukcesów, wsparcie w porażkach, pomoc w życiu codziennym ${ }^{58}$. Częste kontakty, wspólne podejmowanie decyzji, wzajemne wsparcie przeciwstawia się dezorganizacji rodziny oraz ujawnianiu zaburzeń psychonerwowych, powstających na skutek deprywacji potrzeb bezpieczeństwa, emocjonalnych, seksualnych, sensu życia ${ }^{59}$. Ważny jest nie tylko stały kontakt z nieobecnym rodzicem, ale także otrzymywane wsparcie, wspólny codzienny udział w wychowaniu, dyskusje i rozmowy, uczenie odpowiedzialności, samodzielności. Rodzina poprzez wypracowanie wyjątkowej relacji osiagnie poczucie bezpieczeństwa ważne dla każdego jej członka.

Rodziny niepełne czasowo ze względu na zatrudnienie rodzica wymagają jeszcze wielu badań interdyscyplinarnych, które nie tylko wyjaśnią zachodzące zmiany w podstawowej relacji dwóch osób, ale także pozwolą na zbudowanie systemu wsparcia.

\section{Family in the Situation of One Parent's Employment away from the Place of Residence (Summary)}

Among many discussions concerning family numerous debates touch upon the subject of temporarily single-parent families, i.e. the families in which one parent

${ }^{56}$ Fojcik, „Dziecko”, 15.

57 Smolińska, „Tata”, 77.

${ }^{58}$ Fojcik, „Dziecko”; Katarzyna Fenik, „,Rodzina na odległość”, Niebieska Linia 2 (2009); Krzysztof Błachewicz, „Eurosieroty”, Wychowawca 3 (2012).

59 Janiszewski, Rodzina marynarzy, 232-233. 
is temporarily absent. The problem has always been present in pedagogy. The possibilities of going abroad to work were limited for many years. The increase in the number of temporarily single-parent families was observed as result of the Poland's access to the European Union and the availability required in the growing number of jobs and positions. The following social, political and civilisation transformations have enabled unrestricted migration. Parents make the decision to migrate to satisfy economic and psychological needs. However, at the same time they have to be prepared for both the positive and negative consequence of their relocation. Analysis of numerous data forms the basis for distinguishing types of families being temporarily single-parent due to a parent's employment away from home.

Key words: migration; types of temporarily single-parent families; separation results.

\section{Rodzina w sytuacji zatrudnienia rodzica poza miejscem zamieszkania (Streszczenie)}

Wśród wielu zagadnień dotyczących rodziny liczne dyskusje poświęcone są rodzinom czasowo niepełnym, nazywanym niekompletnymi, czyli takim, w których występuje czasowa nieobecność rodzica. Jest to problem, który zawsze był obecny w pedagogice. Możliwości wyjazdów za granicę w celach zarobkowych były przez wiele lat bardzo ograniczone. Z uwagi na wstapienie Polski do Unii Europejskiej oraz obowiązującą w coraz liczniejszych zawodach dyspozycyjność odnotowano wzrost liczby rodzin niepełnych czasowo. Następujące zmiany społeczno-polityczne i cywilizacyjne umożliwiły nieograniczone przemieszczanie się ludzi. Rodzice decydują się na rozłąkę w celu zaspokojenia potrzeb ekonomicznych oraz psychologicznych. Jednocześnie muszą się liczyć się z pozytywnymi, ale również negatywnymi skutkami ich wyjazdów. Analiza licznych badań jest podstawą do wyróżnienia typów rodzin niepełnych czasowo, ze względu na zatrudnienie poza miejscem zamieszkania.

Słowa kluczowe: migracja; rodzaje rodzin czasowo niepełnych; skutki rozłąki.

\section{Bibliografia}

Adamski, Franciszek. Rodzina. Wymiar społeczno-kulturowy. Kraków: Wydawnictwo Uniwersytetu Jagiellońskiego, 2002. 
Auleytner, Julian, Dorota Błaszczyk. „Problemy wychowawcze w rodzinach niepełnych". W: Rodzina w okresie transformacji systemowej, red. Adam Kurzynowski, 177-201. Warszawa: Wydawnictwo Wyższej Szkoły Pedagogicznej Towarzystwa Wiedzy Powszechnej, 1995.

Bakiera, Lucyna. „Generatywność rodziców jako wartość rozwojowa”. W: Rodzina jako wartość w rozwoju czlowieka, red. Barbara Harwas-Napierała, 56-90. Poznań: Wydawnictwo Naukowe UAM, 2009.

Bakiera, Lucyna. „Wartość małżeństwa w rozwoju człowieka dorosłego”. W: Rodzina jako wartość w rozwoju człowieka, red. Barbara Harwas-Napierała, 25-57. Poznań: Wydawnictwo Naukowe UAM, 2009.

Balcerzak-Paradowska, Bożena. „Wpływ okresowej migracji na warunki życia rodziny". Problemy Rodziny 5 (1994): 11-14.

Bieńko, Mariola. „Współczesne skrypty bycia razem. Zamierzony i realizowany projekt scenariuszy ról małżeńskich". Młodzież a Rodzina. Roczniki Socjologii Rodziny XIX (2008-2009): 71-90.

Błachewicz, Krzysztof. „Eurosieroty”. Wychowawca 3 (2012): 16-19.

Castells, Manuel. Siła tożsamości. Warszawa: Wydawnictwo Naukowe PWN, 2009. Chmielewska, Anna. „Środowisko rodzinne jako źródło trudności i wsparcia”. W: Wielość spojrzeń na malżeństwo i rodzinę, red. Anna Kwak, Mariola Bieńko, 177-198. Warszawa: Wydawnictwo Uniwersytetu Warszawskiego, 2012.

Cholewa-Gałuszka, Bogusława. „Zagrożenia realizacji funkcji rodziny”. W: Rodzina w świetle zagrożeń realizacji dotychczasowych funkcji. Szkice monograficz$n e$, red. Wiesława Korzeniowska, Andrzej Murzyn, Urszula Szuścik, 27-33. Katowice: Wydawnictwo Uniwersytetu Śląskiego, 2007.

Danielewicz, Wioletta. „Problemy rodzin czasowo niepełnych ze względu na dhugotrwały pobyt rodziców za granicą". W: Pedagogika społeczna jako dyscyplina naukowa. Stan i perspektywy, red. Ewa Marynowicz-Hetka, Jacek Piekarski, Ewa Cyrańska, 289-295. Łódź: Wydawnictwo Uniwersytetu Łódzkiego, 1998.

Danielewicz, Wioletta. Sytuacja życiowa dzieci w rodzinach migracyjnych. Białystok: Wydawnictwo Trans Humana, 2006.

Danielewicz, Wioletta. „Zagrożenia realizacji funkcji rodziny”. W: Pomoc dziecku i rodzinie w środowisku lokalnym, red. Wioletta Danielewicz, Jadwiga Izdebska, Beata Krzesińska-Żach, 37-82. Białystok: Wydawnictwo Trans Humana, 1999.

Denek, Kazimierz. „Migracja zarobkowa młodych Polaków”. Nowa Szkoła 7 (2009): $16-21$.

Dyoniziak, Ryszard. Sytuacja psychospołeczna rodzin, w których główni żywiciele przebywaja okresowo za granica. Kraków: Akademia Ekonomiczna, 1988. 
Fenik, Katarzyna. „Rodzina na odległość”. Niebieska Linia 2 (2009): 22-24.

Fidelus, Anna. „Gdy rodzice emigrują...”. Nowa Szkoła 6 (2008): 37-43.

Fojcik, Małgorzata. „Dziecko a migracja zarobkowa rodziców”. Życie Szkoły 7 (2007): 12-15.

Gizicka, Dorota, Julia Gorbaniuk, Małgorzata Szyszka. Rodzina w sytuacji rozłaki migracyjnej. Lublin: Wydawnictwo Katolickiego Uniwersytetu Lubelskiego, 2010.

Głowiak, Krzysztof. „Wyjazdy zagraniczne zagrożeniem funkcjonowania rodzin”. Problemy Opiekuńczo-Wychowawcze 5 (2012): 57-59.

Greenstone, James L., Sharon C. Leviton. Interwencja kryzysowa. Gdańsk: Gdańskie Wydawnictwo Psychologiczne, 2004.

Grudziński, Andrzej. „Funkcjonowanie rodziny w kontekście migracji zarobkowej zarys problemu". W: Senior i rodzina, red. Marek Banach, Adam Szwedzik, 161-170. Kraków: Biblioteka Instytutu Pracy Socjalnej Uniwersytetu Pedagogicznego im. Komisji Edukacji Narodowej w Krakowie, 2013.

Harwas-Napierała, Barbara. „Rodzina jako wartość a współczesność”. W: Rodzina jako wartość w rozwoju człowieka, red. Barbara Harwas-Napierała, 11-24. Poznań: Wydawnictwo Naukowe UAM, 2009.

Iwanek, Michał. Readaptacja żotnierzy powracajacych z misji wojskowych poza granicami państwa. Warszawa: Wojskowe Biuro Badań Społecznych, 2011.

Janiszewski, Ludwik. Rodzina marynarzy i rybaków morskich. Warszawa-Poznań: PWN, 1976.

Kawczyńska-Butrym, Zofia. Migracje. Wybrane zagadnienia. Lublin: Wydawnictwo Uniwersytetu Marii Curie-Skłodowskiej, 2009.

Kawula, Stanisław. „Rodzinne konteksty polskiej polityki społecznej”. W: Praca socjalna i polityka spoteczna. Obszary wspótdziałania wobec wykluczenia spotecznego, red. Krystyna Marzec-Holka, Anna Rutkowska, Magdalena Joachimowska, 43-58. Bydgoszcz: Wydawnictwo Uniwersytetu Kazimierza Wielkiego, 2008.

Kołaczek, Bożena. „Sytuacja społeczna i ekonomiczna rodzin niepełnych w Polsce". W: Samotne rodzicielstwo a zagrożenie wykluczeniem spolecznym, red. Bożena Balcerzak-Paradowska, 29-69. Warszawa: Instytut Pracy i Spraw Socjalnych, 2014.

Kozdrowicz, Ewa. „Psychospołeczne skutki rozłąki migracyjnej”. W: Szkoła wobec mobilności zawodowej rodziców i opiekunów, red. Ewa Kozdrowicz, Bartłomiej Walczak, 21-37. Warszawa: Centrum Metodyczne Pomocy Psychologiczno-Pedagogicznej, 2008.

Kozdrowicz, Ewa. Sytuacja dziecka w rodzinie samotnej matki. Warszawa: Wydawnictwo Uniwersytetu Warszawskiego, 1989. 
Kwak, Anna. „Od i do małżeństwa i rodziny: «czas» rodziny - «czas» jednostki”. W: Wielość spojrzeń na malżeństwo i rodzinę, red. Anna Kwak, Mariola Bieńko, 39-60. Warszawa: Wydawnictwo Uniwersytetu Warszawskiego, 2012.

Lewicka, Monika. Wybory życiowe studentów: matżeństwo - rodzina - formy alternatywne. Bydgoszcz: Wydawnictwo Uniwersytetu Kazimierza Wielkiego, 2014.

Matyjas, Bożena. Dzieciństwo w kryzysie. Etiologia zjawiska. Warszawa: Wydawnictwo Akademickie Żak, 2008.

Miłkowska, Grażyna, Anna Kulesza. „Wpływ emigracji zarobkowej rodziców na funkcjonowanie dzieci w rodzinie i szkole”. Problemy Opiekuńczo-Wychowawcze 9 (2009): 3-15.

Mituła, Edyta. „Rodziny pełne nie w pełni - eurosieroctwo. Opieka nad dzieckiem a migracja zarobkowa rodziców". W: Rodzina a wspótczesność, red. Andrzej Ładyżyński, 163-183. Wrocław: Wydawnictwo Oświatowe ATUT, 2009.

Najder, Marta. „Zagrożenia współczesnej rodziny”. W: Rodzina a współczesność, red. Andrzej Ładyżyński, 239-243. Wrocław: Wydawnictwo Oświatowe ATUT, 2009.

Nowak, Marta, Agnieszka Gawęda, Małgorzata Janas-Kozik. „Zjawisko eurosieroctwa a kierunki pracy terapeutycznej i leczenia psychiatrycznego - prezentacja przypadku". Psychiatria Polska 2 (2012): 295-304.

Psychologiczne portrety człowieka, red. Anna Izabela Brzecińska. Gdańsk: Gdańskie Wydawnictwo Psychologiczne, 2005.

Rawa-Kochanowska, Anita. „Obraz rodziny u «sierot emigracyjnych»”. W: Rodzina w sieci wartości. Religia, praca i czas wolny, red. Wojciech Muszyński, 310-321. Toruń: Wydawnictwo Adam Marszałek, 2010.

Rigamonti, Magdalena. „Niewidoczne rany. Wywiad z S. Ilnickim”. Newsweek, 01 marca 2012 12:00, ostatnia aktualizacja 01 marca 2012, http://spoleczenstwo. newsweek.pl/niewidoczne-rany,88754,1,1.html, [dostęp: 19.01.2013 r.].

Romaniuk, Ryszard. „Porada”. Niebieska Linia 4 (2009): 30-32.

Rostowski, Jan, Teresa Rostowska. „Małżeństwo - wczoraj, dzisiaj i jutro - w perspektywie psychologicznej”. W: Człowiek u progu trzeciego tysiqclecia. Zagrożenia $i$ wyzwania, red. Mieczysław Plopa, 229-242. Elbląg: Wydawnictwo Elbląskiej Uczelni Humanistyczno-Ekonomicznej, 2005.

Sadowska, Agnieszka. „Migracja rodziców źródłem dysfunkcjonalności środowiska wychowawczego dziecka". W: Zagrożenia i problemy współczesnej rodziny, red. Sylwester Bębas, 37-47. Radom: Wydawnictwo Wyższej Szkoły Handlowej, 2011.

Slany, Krystyna. Alternatywne formy życia matżeńsko-rodzinnego w ponowoczesnym świecie. Kraków: Nomos, 2008. 
Slany, Krystyna. „Małżeństwo i rodzina w zglobalizowanym świecie”. Problemy Rodziny 4/5/6 (2001): 3-10.

Slany, Krystyna. „Ponowoczesne rodziny - konstruowanie więzi i pokrewieństwa”. W: Zagadnienia malżeństwa i rodzin $w$ perspektywie feministyczno-genderowej, red. Krystyna Slany, 45-64. Kraków: Wydawnictwo Uniwersytetu Jagiellońskiego, 2013.

Smolińska, Barbara. „Tata na emigracji”. Charaktery 7 (2008): 76-77.

Tarnowska-Jakóbiec, Urszula. Rodziny marynarzy i rybaków dalekomorskich jako środowisko wychowawcze. Szczecin: Wydawnictwo Uniwersytetu Szczecińskiego, 1998.

Tarnowska-Jakóbiec, Urszula. „Warunki rozwoju dzieci i młodzieży w rodzinie ludzi morza". W: Wspótczesne rodziny polskie w okresie radykalnych zmian spolecznych, red. Ludwik Janiszewski, 219-250. Szczecin: Wydawnictwo Uniwersytetu Szczecińskiego, 1998.

Tyszka, Zbigniew. „Istotne zmiany w socjalizacji rodzinnej”. Problemy Rodziny 2-3 (2000): 29-37.

Tyszka, Zbigniew. Rodzina we wspótczesnym świecie. Poznań: Wydawnictwo Naukowe UAM, 2002.

Tyszkowa, Maria. „Jednostka a rodzina: interakcje, stosunki, rozwój”. W: Psychologia rozwoju człowieka, red. Maria Przetacznik-Gierowska, Maria Tyszkowa, 124-150. Warszawa: Wydawnictwo Naukowe PWN, 2000.

Tyszkowa, Maria. „Rodzina, doświadczenie i rozwój jednostki”. W: Rodzina a rozwój jednostki, red. Maria Tyszkowa, 13-37. Poznań: Nakładem Centralnego Programu Badań Podstawowych, 1990.

Tyszkowa, Maria. „Rozwój psychiczny jednostki jako proces strukturacji i restrukturacji doświadczenia". W: Rozwój psychiczny człowieka w ciagu życia. Zagadnienia teoretyczne i metodologiczne, red. Maria Tyszkowa, 47-79. Warszawa: Wydawnictwo Naukowe PWN, 1988.

Urbańska, Sylwia. „«Cała Polska liczy eurosieroty». Panika moralna i płeć w wykluczeniu oraz stygmatyzacji rodzin migrantów". Kultura i Spoleczeństwo 3 (2010): 61-88.

Walczak, Bartłomiej. Społeczne, edukacyjne i wychowawcze konsekwencje migracji rodziców i opiekunów prawnych uczniów szkót podstawowych, gimnazjalnych i ponadgimnazjalnych, projekt badawczy. Warszawa: Wydawnictwo Pedagogium, Wyższa Szkoła Pedagogiki Resocjalizacyjnej w Warszawie, 2009.

Walczak, Bartłomiej. „Wychowawcze i edukacyjne konsekwencje «euromigracji» rodziców i opiekunów". Problemy Opiekuńczo-Wychowawcze 5 (2008): 21-26.

Winiarczyk, Anna. „Migracje zarobkowe jedną z przyczyn niepełności rodziny”. Pedagogika Rodziny 1 (2011): 71-80. 
Zawisza-Masłyk, Ewa. „Wokół pojęcia «eurosieroctwo»”. Opieka, Wychowanie, Terapia 3-4 (2008): 40-42.

Zdrowotne i psychospołeczne skutki udziału żotnierzy WP w misjach poza granicami kraju, oprac. Marian Kloczkowski, Łukasz Kiciński. Warszawa: Wojskowe Biuro Badań Społecznych, 2010.

Zubrzycka, Elżbieta. Narzeczeństwo, matżeństwo, rodzina, rozwód? Gdańsk: Gdańskie Wydawnictwo Psychologiczne, 1993.

Żak, Monika. Życie rodzinne w sferze zawodów wysokiego ryzyka (na przykładzie zawodu policjanta). Katowice: Wydawnictwo Uniwersytetu Śląskiego, 2015. 